\title{
An Analysis of Wuthering Heights from the Gothic Traditional Perspective
}

\author{
Lin Jia ${ }^{1, a}$, Xiaomei Zhü,b \\ ${ }^{1}$ Lin Jia, Hebei University, Baoding, Hebei, China \\ ${ }^{2}$ Xiaomei Zhu, Hebei University, Baoding, Hebei, China \\ a18832953265@163.com, b2538602843@qq.com
}

Keywords: Wuthering Heights, Gothic.

\begin{abstract}
Emily Bronte, the 19th-century British writer, occupies an important and unique position in British literary history and though she only had one novel---Wuthering Heights, she was still one of the most influential writers in the world literature. The paper will analyze the gothic style in Wuthering Heights mainly from four aspects, including the theme selection, characterization, depiction of the environment and the use of supernatural factors.
\end{abstract}

\section{Introduction}

Emily Bronte, the 19th-century British writer, was born in a poor clerical family. The Bronte sisters were influenced by the gothic style as a whole. Wuthering Heights, Emily's masterpiece, integrated romanticism and realism with strong gothic style. But this work wasn't recognized when it was firstly published. With the further study, it re-entered people's visions. Its strong emotions, plotsuspended narrative technique and portrayed characters made it reinvigorate gloriously.

Gothic novel, mainly back to the Middle Ages, described the stories taking place in the deserted places like castles, cloisters, ruins and wasteland, etc. It mainly focused on the theme of hatred and succession struggles. The plots were horrible and thrilling and full of murders, revenge and also many supernatural phenomena (like the ghost), which created a ghastly, mysterious, horrible and suspenseful atmospheres with the main characteristics of horror, mystery and weirdness. Wuthering Heights, a work fully possessing gothic color, typically reflected the features of the gothic novel.

\section{Theme Selection}

In presenting the theme, the author Emily Bronte continued with the features of the gothic novel. The novel began when old Earnshaw of the Wuthering Heights took the orphan Heathcliff home. Since then, Heathcliff stayed there and became a good playmate with Catherine Earnshaw who was old Earnshaw's daughter. Once, Catherine stayed in Thrushcross Grange to recover. When she got home, she began to behave like a cultured and superior lady. Her attitude towards Heathcliff was not as good as before. In such circumstances, Heathcliff disappeared after hearing the news that Catherine accepted the host of Thrushcross Grange---Edgar Linton's proposal. After getting married, Catherine scraped through her life with contradictions and remorse. Unexpectedly, Heathcliff came back. Because of illness, Catherine was stimulated mentally and got schizophrenia. Heathcliff turned to Isabella Linton for love and tempted her to elope with him. However, Catherine died after she gave her daughter Catherine Linton's birth. Facing the death of Catherine, Heathcliff decided to revenge. After getting married, Isabella was imprisoned and after her escape, she gave birth to her son Linton Heathcliff who was later taken away by Edgar. After the death of Snyder, Heathcliff took away the Wuthering Heights. Heathcliff brought little Linton back. Heathcliff treated Hareton in a cruel way and treated Earnshaw with civilized education. When Edgar was seriously ill, Heathcliff compelled little Catherine and Linton to get married. Soon frail and sick little Linton also died. Little Catherine and Hareton had fallen love with each other. The sight of little kids reminded Heathcliff of the period when he and Catherine were young, and Heathcliff died after fasts.

The theme of the novel centered on revenge which was the central clue throughout the whole 
novel. When Heathcliff grew up, he returned to the Wuthering Heights for revenge; knowing that Catherine got married, Heathcliff chose Edgar's sister as an instrument of his revenge to be married with her; after the marriage, he kicked and imprisoned his wife and claimed the ownership of the Wuthering Heights through gamble, which aggravated Snyder's disease and contributed to his death indirectly; Heathcliff extended his plan of revenge to the next generation. He forced little Catherine and little Linton to be married. The interlocking plots were tied together by the chain of revenge. It also contained some fights over the succession, which reflected the gothic color.

\section{Characterization}

In this novel, the writer created a series of full characters, like Heathcliff, Catherine and Isabella.

3.1 Heathcliff. The writer shaped Heathcliff into a consummate villain. He was a gypsy of discrimination with dark and dirty look and being dressed in rags. His image was portrayed by the writer from three stages.

The first stage was Heathcliff's just arrival at the Wuthering Heights. At that time, he was gloomy and endurable even facing Snyder's fists. Because of that, Heathcliff hated Snyder very much. And Catherine, a rebellious girl, gradually started her progression from dislike to like. And they often played together. During his growth, a detail was very notable: old Earnshaw gave a good horse to Heathcliff and Snyder became disgruntled. Snyder hit Heathcliff and forced to take the horse. However, Heathcliff didn't choose to hit back as a resistance. Instead, he turned to old Earnshaw to complain about it. So Snyder was punished and Heathcliff kept his own thing. It proved that young Heathcliff was very mature in thinking and he was aware that only power could force others to yield. The second stage referred to the period when Heathcliff got along with Catherine. Catherine, longing for emancipatory nature, often played with Heathcliff and made a lot of troubles. Heathcliff was happy when he was faced with Catherine, but not for long. Catherine empathized with Edgar, which was a devastating blow to Heathcliff. Just because of that intense stimulation, Heathcliff couldn't resist his anger anymore and started his way of revenge. The third stage was Heathcliff's return. He was gloomy, cruel and wild. He hated the whole world and kept revenging at all costs, even let himself be an instrument of his revenge. Through gamble, he took away the Wuthering Heights; taking advantage of Isabella, he took revenge on Catherine; he compelled the next generation to do things the way he wanted to do them in order to meet his nearly abnormal ideas.

Through the three stages, Heathcliff, a vicious and gloomy image, was reflected onto the paper, walking along the dark path of revenge.

3.2 Catherine. Similarly, Catherine also showed her gothic features. When she was a kid, Catherine had the desire of longing for nature. She always got into troubles though she had no bad intention, which gave her babysitter headaches. Meanwhile, she played with Heathcliff without tained glasses like others. During her stay in the Thrushcross Grange, Catherine became polite and educated, but also vainglorious. It promoted her to accept Edgar's proposal. After getting married, Catherine didn't live a happy life as she expected. Instead, she scraped through her life with contradictions and remorse, which was a conflict between nature and civilization. Heathcliff represented nature and what was behind Edgar was civilization. In essence, that choose whom to be married was the battle between nature and civilization. The conflict made Catherine upset. She suffered a lot with schizophrenia and finally she had to taste the bitter fruits made by herself after their elopement.

3.3 Isabella. Isabella was the typical heroine in the traditional gothic novel. She was beautiful, delicate, sensitive and passive. As to Heathcliff's courtship, she got deeply stuck with great complacency and allowed herself to indulge in fantasies. After getting married with Heathcliff, she was imprisoned and was driven into a tight corner; knowing the truth, she chose to run away. Both mentally and behaviorally, she reflected the features of the typical heroine in the traditional gothic novel. 


\section{Depiction of the Environment}

The writer transplanted the background of medieval castle in the gothic novel to the wasteland in the real life in the north of Elizabethan England. She combined reality with weirdness, which was ahead of her time and has taken the lead at that time.

Wuthering Heights presented by the writer was very horrible. The windows there were small with a lot defensive stones. There were a lot of weird sculptures. Living in such an environment, wind-torn trees would become gaunt, let alone the children. The three kids, Snyder, Catherine and Heathcliff, had different natures, but all of them were irritable and hysterical. However, look at the Thrushcross Grange, a pleasant place with many scarlet cushions here and there and mild candlelights in the house. People would become gentle with a mild living condition. From Edgar and Isabella, we felt the existence of golden mean. They didn't have strong emotions and any of their own.

\section{Use of Supernatural Factors}

In this novel, the writer used a lot of supernatural factors, like nightmares, graveyards, delusion and ghosts, etc to heighten the mysterious and weird atmosphere.

5.1 The Tenant's Dream. The writer conveyed the Wuthering Heights's mystery to the reader with the aid of the tenant's feelings. The tenant had a vivid and terrible dream when he stayed in the Wuthering Heights for the night. In his dream, the branch of a fir tree scratched the window. He broke the glass only to grasp a cold finger not the branch. The owner of the finger sobbed in a gloomy voice, "Let me in... let me in." Asked who she was, she said she was Catherine Linton. The tenant recognized the kid's face and put her wrist to rub on the broken glasses back and forth. With blood on her, she shouted to come in and said that she had been vagrant for 20 years. Reading this, we looked at the Wuthering Heights with the tenant and explored its secrets. The writer created a mysterious and suspenseful manor, which attracted readers to explore with the tenant nervously.

5.2 Catherine's illness. After getting married with Edgar, Catherine felt distressed not happy. She was surrounded by the longstanding conditions and she was overwhelmed with serious schizophrenia. She kept murmuring that Nelly Dean was an old witch, and there was a face in the closet (actually it was a mirror). She couldn't even tell whether she was the girl in the Wuthering Heights or the lady in the Thrushcross Grange when she was in a bad situation. In our daily life, it is difficult for us to come into contact with people who are mentally ill. Even if we meet this kind of person, we are always very cautious facing them for fear that what we have said and done would irritate them. The writer arranged a strong conflict for Catherine. She couldn't bear it anymore and collapsed finally. Maybe, being schizophrenic could make Catherine be herself. Her abnormal and terrible behaviors added to the gloomy and horrible tone of living in the manor.

5.3 Heathcliff Dug the Grave at Midnight. After Catherine's death, Heathcliff's mental state was poor. It was said by himself that he thought the only obstacle between him and Catherine was the two-yards-thick loess. So he went to the cemetery to dig the grave and want to embrace Catherine again. Heathcliff touched the coffin and prepared to open it. He heard someone sigh, but there was no living creature. Heathcliff knew that it was from Catherine and she wasn't buried in the ground but still alive. Through these creepy descriptions, we felt the horrible ghost that could sigh and be touched like a real person. Ghost, the general element used in the gothic novel, is invisible and omnipotent. Nobody can find its whereabouts and guess its minds. The dreaded ghost depicted by the writer heightened the horrific and gloomy atmosphere of the novel.

5.4 Heathcliff's Dead Look and His Drifting Ghost. Heathcliff started his fast and got to the end of his life. According to the words, we have seen a dying Heathcliff who had dark and deeper eyes. His pale face formed a strong contrast with the dark eyes, which made people associate death inevitably. It couldn't be more right to describe Heathcliff as an evil spirit. Heathcliff was about to die, kept calling Catherine with hallucinations and wandered out at night. Finally, Heathcliff died and his dead look was very horrible. His eyes were sharp and fierce, but it seemed that he was smiling. Then, the writer brought the horrible atmosphere to a climax. Heathcliff's ghost travelled around the church, field, and the house. It looked out of the window and was seen by a shepherd 
boy in a rainy and dark night. We heard a more terrible legend from the villagers that we couldn't tell what was real and what was imagined.

\section{Summary}

Compared with the Victorian mainstream novel, Wuthering Heights seemed to be very incompatible. It was isolated Emily Bronte who finished this mysterious novel in her short life. Emily inherited the romantic traditions and used vivid figures, mysterious manor, stormy weather and horrible plots, which reflected the features of the gothic novel to readers thoroughly. Her elaborate artistic conception, astonishing choice of theme, emotional characterization and successful application of gothic technique, made Wuthering Heights reveal strong vitality exceeding the limit of the space and time. It stood among the long corridor of English literature solemnly and distinctively.

\section{References}

[1] Emily Bronte. Wuthering Heights[M]. Bantam Classics, 1983

[2] Barnard, Robert. Emily Bronte[M]. Shanghai: Shanghai Foreign Language Education Press, 2009

[3] Bloom, Harold. Emily Bronte's Wuthering Heights (Bloom's Guides)[M]. New York: Infobase Publishing, 2008

[4] Ruth M. Adams. Wuthering Heights: The Land East of Eden[J]. Nineteenth-Century Fiction, Vol.13 No.1 (Jun.1958) 